\title{
Meta-Analysis: Satu Dekade Penelitian Manajemen Laba di Indonesia
}

\author{
Nur Eny \\ Universitas Negeri Makassar \\ nurenylolo@gmail.com
}

\begin{abstract}
This study aims to examine whether corporate characteristics and information asymmetry affects earnings management in Indonesia. This study use meta-analysis techniques approach with 35 samples from international and national accredited journals as well as Indonesian National Symposium of Accounting proceedings. Research results reinforce meta- analysis findings of previous studies where earnings management is done for different purposes. Management's motivation to perform earnings management varies between opportunistic and efficient contract motives. Empirical evidence shows that corporate characteristics are predictors of earnings management. Cash flow from operations and information asymmetry significantly affect earnings management. This empirical evidence supports several previous meta-analysis in accounting field where moderator measurement variables has an effect on heterogeneity of research findings.
\end{abstract}

Keywords: earnings management, corporate characteristics, information asymmetry, meta-analysis

\begin{abstract}
Abstrak
Studi ini meneliti faktor-faktor yang mempengaruhi manajemen laba di Indonesia, yaitu karakteristik perusahaan, asimetri informasi. Studi ini menggunakan pendekatan teknik analisis-meta, sampel terdiri dari 35 hasil penelitian dari jurnal yang diterbitkan yang terakreditasi nasional dan internasional maupun dari prosiding Simposium Nasional Akuntansi. Hasil analisis meta memperkuat temuan penelitian-penelitian sebelumnya bahwa manajemen laba dilakukan untuk tujuan yang berbeda dan motivasi manajemen untuk melakukan manajemen laba masih bervariasi yaitu oportunis dan untuk kontrak efisien. Bukti empiris menemukan bahwa karakteristik perusahaan merupakan prediktor manajemen laba, dan secara robust casf flow from operation dan asimetri informasi berpengaruh terhadap manajemen laba. Temuan mendukung beberapa analisis meta dalam bidang akuntansi yang dilakukan sebelumnya bahwa pengukuran variabel memilki efek moderator sehingga menjadi penyebab heterogenitas temuan dalam suatu bidang penelitian. Studi ini juga memperoleh bukti empiris efek moderator untuk pengukuran variabel explanatory yaitu pengukuran tingkat pertumbuhan (growth) dan pengukuran profitabilitas.
\end{abstract}

Kata Kunci: manajemen laba, karakteristik perusahaan, asimetri informasi, analisis meta 


\section{PENDAHULUAN}

Fenomena manajemen laba meskipun bukan merupakan masalah baru, popularitasnya tetap menarik perhatian dari regulator, investor, analis keuangan dan peneliti akademis. Hal ini memiliki alasan karena praktik manajemen laba semakin meningkat seiring perkembangan dunia bisnis selama beberapa dekade terakhir. Manajemen laba tidak hanya dilakukan oleh perusahaan-perusahaan di negara-negara berkembang seperti Indonesia, tetapi juga dilakukan oleh perusahaan-perusahaan di negara-negara maju dimana sistem bisnisnya telah tertata dengan baik, seperti Amerika Serikat (Mulford dan Comeskey, 2002; Gu dan Lee, 2002).

Hasil investigasi SEC telah menemukan praktik manajemen laba yang telah mengancam batas-batas Generally Accepted Accounting Principle (GAAP), bahkan sudah sangat ekstrim yang mengarah pada kecurangan laporan keuangan. Ada beberapa faktor mempengaruhi manajemen laba yang telah diteliti oleh beberapa peneliti sebelumnya, antara lain karakteristik perusahaan (Yangseon dkk, 2003), tingkat pengungkapan (Lobo dan Zhou, 2001), Asimetri Informasi (Richardson, 1998); mekanisme corporate governance (Chtourou, 2001; Ali dkk, 2009), reputasi auditor, dewan direksi, leverage (Dechow dkk, 1995).

Penelitian terhadap berbagai faktor yang mempengaruhi manajemen laba telah dilakukan di Indonesia oleh beberapa peneliti. Beberapa dari penelitian tersebut menunjukkan hasil yang konsisten maupun tidak konsisten dengan tingkat signifikansi yang berbeda. Mereka memperoleh bukti bahwa praktik perataan laba terjadi pada perusahaan di Indonesia dan mengindikasikan bahwa faktor-faktor yang mendorong praktik perataan laba antara lain adalah ukuran perusahaan (size), leverage operasi, dan sektor industri.

Penelitian-penelitian yang telah dilakukan memberikan sejumlah pemahaman berbagai faktor yang mempengaruhi manajemen laba, namun temuan dari penelitian-penelitian tersebut masih sangat bervariasi dan masih ada pertentangan satu sama lain, dan mungkin ada beberapa dari penelitian-penelitian tersebut yang menyulitkan dalam menarik kesimpulan substantif. Dengan demikian, untuk menguji validitas dan daya generalisasi dari penelitian substansial yang sudah dilakukan dalam suatu bidang penelitian, perlu dilakukan sintesa dan menilai penelitian-penelitian empiris yang relevan dengan tema tesebut. Untuk melakukan analisis secara kuantitatif terhadap beberapa hasil penelitian primer, dapat dilakukan dengan pendekatan analisis-meta (Meta-Analysis). Analisis-meta dilakukan dengan tujuan untuk mengintegrasikan temuan-temuan yang ada. Analisis-meta memiliki makna sebagai analisis secara ketat (rigorous) yang dilakukan sebagai alternatif terhadap pembahasan secara naratif dan bernada informal (casual) yang biasa dilakukan untuk mengulas tentang penelitian-penelitian yang sudah dilakukan, seperti yang biasa dilakukan untuk memahami sebuah bidang keilmuan yang sedang mengalami pertumbuhan secara pesat (Hunter dan Schmidt, 1990).

Konsep manajemen laba umumnya didasari teori agensi yang menyatakan bahwa praktik manajemen laba dipengaruhi oleh konflik kepentingan antara manajemen (agent) dan pemilik (principal) yang timbul ketika setiap pihak berusaha untuk mencapai tingkat 
kemakmuran yang diinginkan. Dalam hubungan agensi tersebut, manajer dengan asimetri informasi yang dimilikinya mendapat peluang untuk memaksimalkan kepentingannya. Hal ini mendorong agen (manajer) untuk memikirkan bagaimana angka akuntansi tersebut dapat digunakan sebagai sarana untuk memaksimalkan kepentingannya yang pada akhirnya mengarah pada praktik manajemen laba.

Faktor-faktor yang mempengaruhi manajemen laba antara lain yaitu: Reaksi investor (return saham), karakteristik perusahaan (leverage, size, likuiditas, jenis industri), pengungkapan, asimetri informasi, dan mekanisme corporate governance. Berbagai penelitian yang telah menguji berbagai faktor yang mempengaruhi manajemen laba.

Karakteristik perusahaan yang diproksi sebagai rasio keuangan seperti ukuran perusahaan (size), tingkat profitabilitas, leverage, dan sebagainya diprediksi mempengaruhi manajemen laba. Berbagai penelitian empiris terdahulu telah menguji variabel-variabel tersebut, namun temuan yang ada masih menunjukkan simpulan yang berbeda karena beberapa variabel masih disimpulkan tidak berpengaruh signifikan terhadap manajemen laba.

Temuan-temuan dari penelitian-penelitian terhadap faktor-faktor yang mempengaruhi manajemen laba yang ada masih bervariasi dengan tingkat signifikansi yang berbeda. Penelitian-penelitian tersebut belum dapat memberikan kesimpulan faktor mana yang paling robust yang dapat mempengaruhi terjadinya praktik manajemen laba, apakah karaktersitik perusahaan yang diproksi oleh rasio keuangan seperti ukuran perusahaan (size), tingkat leverage (LEV), pertumbuhan (growth) dan profitabilitas, atau asimetri informasi atau faktor lain. Namun demikian, berbagai bukti empiris dalam penelitianpenelitian individu telah menemukan secara signifikan meskipun bervariasi, bahwa faktor-faktor tersebut (Karakteristik perusahaan, asimetri informasi) mempengaruhi manajemen laba.

Asimetri informasi (information asymmetry) yaitu suatu kondisi di mana ada ketidakseimbangan perolehan informasi antara pihak manajemen (agent) dengan pihak pemegang saham dan stakeholders sebagai pengguna informasi (user). Asimetri informasi yang dimiliki manajer, berarti manajer mendapat kesempatan untuk bertindak oportunis, yaitu memperoleh keuntungan pribadi, yang mengarah pada tindakan melakukan manajemen laba (earnings management) yang akan menyesatkan pemilik (pemegang saham) mengenai kinerja ekonomi perusahaan. Dengan demikian dapat diajukan hipotesis bahwa, ukuran Perusahaan (size), Leverage ( $L E V$ ), Pertumbuhan (growth, Cash flow from operation (CFO) Asimetri informasi berpengaruh terhadap manajemen laba.

Pemilihan model pengukuran yang berbeda untuk memisahkan akrual menjadi komponen diskresionari dan non-diskresionari menghasilkan variasi dalam penelitian-penelitian manajemen laba yang ada. Model Jones dan Jones modifikasi yang banyak digunakan dalam penelitian manajemen laba, sejalan dengan penelitian yang dilakukan oleh García-Meca dan Sanchez-Ballesta (2009) bahwa menurut Dechowd dkk, (1995) model dari Jones (1991) dan model Jones yang dimodifikasi yang banyak digunakan karena dianggap sederhana. Model-model tersebut berisi dua versi dari total akrual dan akrual modal kerja (working 
capital accrual), (total akrual = akrual modal kerja dikurangi pengeluaran depresiasi dan amortisasi untuk periode yang bersangkutan).

Selanjutnya analisis-meta akan memungkinkan kita untuk mengevaluasi apakah heterogeneitas (keanekaragaman) dalam bidang penelitian ini adalah didasarkan pada estimasi-estimasi dari model pengukuran yang ada.

Penelitian ini akan menganalisa efek moderator dari berbagai definisi operasional yang berbeda-beda dari manajemen laba yang terkait dengan model pengukuran yang digunakan dalam penelitian-penelitian manajemen laba di Indonesia yang masuk analisis. Sebuah variabel moderator adalah variabel yang menyebabkan perbedaan dalam korelasi antara dua variabel lain. Faktor moderator ini dianalisis hanya jika jumlah penelitiannya memadai untuk dilakukan analisis-meta. Dengan demikian dihipotesiskan bahwa model pengukuran manajemen laba memoderasi hubungan antara corporate size, leverage, pertumbuhan perusahaan (growth), profitabilitas dengan manajemen laba.

Pengukuran terhadap variabel-variabel penjelas (explanatory variable) bisa menjadi efek moderator terhadap hubungan antara variabel-variabel independen atau penjelas (explanatory variabel) dengan variabel dependen (García-Meca dan Sanchez-Ballesta, 2009). Dalam penelitian ini pengujian dilakukan untuk mengetahui apakah konsep pengukuran yang sama digunakan pada sebagian besar dalam penelitian-penelitian individu, dan definisi operasional yang berbeda dari variabel independen (explanatory) bisa menjadi moderator bagi hubungan antara variabel independen dengan manajemen laba.

Penelitian ini akan meguji apakah variasi dari temuan yang ada dimoderasi oleh pengukuran variabel-variabel karakteristik perusahaan (profitabilitas, leverage, size, growth dan Cash flow from operation dan asimetri informasi). Dengan demikian diajukan hipotesis bahwa pengaruh corporate size. Leverage, corporate growth, profitabilitas, cash flow from operation terhadap manajemen laba dimoderasi oleh pengukuran corporate size, leverage, corporate growth, profitabilitas dan cash flow from operation.

Penelitian ini akan mengidentifikasi penelitian-penelitian empiris yang relevan tentang manajemen laba di Indonesia, yang telah menyelidiki berbagai faktor yang mempengaruhi manajemen laba. Penelitian ini akan mengintegrasikan temuantemuan penelitian-penelitian sebelumnya, melakukan generalisasi secara kuantitatif, dan mencari efek atau hubungan yang tidak terjelaskan jika dilihat dengan cara lain dalam meringkas suatu hasil dari sekelompok penelitian primer yang sama, seperti pendekatan naratif.

Penelitian ini melakukan analisis-meta, dimana metode analisis meta dalam bidang akuntansi khususnya terkait dengan variable-varibel prediktor manajmen laba hampir belum pernah dilakukan di Indonesia. Analisis-meta merupakan metodologi tinjauan kuantitatif yang sudah diterima secara luas di dalam penelitian medis dan psikologi serta dalam disiplin lain termasuk ekonomi, manajemen maupun akuntansi di dunia. 


\section{METODE}

Penelitian ini menggunakan pendekatan penelitian studi literatur, dimana akan mengkaji hasil-hasil penelitian (literatur) manajemen laba. Menggunakan alat analisis yaitu analisis-meta yang bertujuan untuk menggabungkan beberapa penelitian sejenis (penelitian manajemen laba) dengan memakai tehnik statistika sehingga diperoleh paduan data secara kuantitatif (Lyons, 2000; Hunter dan Schmidt, 2004).

Tehnik analisis-meta dilakukan dengan membuat rekapitulasi fakta dari ringkasan prosedur statistik yang ada dalam penelitian-penelitian manajemen laba yang dikaji (penelitian yang masuk dalam analisis), menentukan dan mengukur kekuatan dari sebuah efek dari hubunganhubungan variabel manajemen laba dengan variabel-variabel yang mempengaruhinya, meneliti variabel-variabel apa yang memoderasi kekuatan dari efek tersebut dengan melakukan integrasi dan memberikan intepretasi secara teotiritis berdasarkan kalkulasi statistik yang ditemukan. Penelitian ini akan menganalisis hasil-hasil penelitian manajemen laba di Indonesia selama tiga belas tahun sejak tahun 2000 sampai 2012 karena periode tersebut dianggap cukup memadai dan representative dalam menangkap perkembangan sebuah penelitian.

Data yang digunakan dalam penelitian ini adalah data sekunder yaitu berupa artikel penelitian manajemen laba yang terdiri dari; 1) Artikel penelitian manajemen laba di Indonesia yang terpublikasi baik di jurnal yang diterbitkan di Indonesia maupun di luar negeri. 2) Artikel penelitian manajemen laba yang berasal dari prosiding Simposium Nasional Akuntansi. jumlahnya yang memilki kriteria dan karakteristik untuk dimasukkan dalam analisis-meta di dalam penelitian ini.

Obyek penelitian yang disertakan dalam analisis-meta pada penelitian ini memilki karakteristik sebagai berikut: Penelitian-penelitian manajemen laba yang meneliti hubungan antara berbagai faktor yang mempengaruhi manajemen laba secara kuantitatif. Penelitian ini menganalisis penelitian-penelitian manajemen laba akrual, sedangkan penelitian manajemen laba riil tidak dimasukkan dalam analisis karena jumlah penelitiannya masih relatif sedikit untuk dilakukan analisis meta. Penelitian-penelitian manajemen laba yang menempatkan proksi manajemen laba sebagai variabel dependen atau variabel yang dijelaskan. Variabelvariabel independen yang dimasukkan dalam analisis ditentukan berdasarkan jumlah penelitian yang cukup mamadai untuk dilakukan analisis-meta.

Analisis statistik (teknik analisis-meta), meliputi; Mengkonversi atau melakukan transformasi statistik ukuran efek dari tiap-tiap penelitian menjadi suatu metrik bersama yaitu (r), dimana ukuran efek tersebut (r) yang akan digunakan untuk melakukan pengakumulasian perbandingan dan intergrasi. Mengelompokkan proksi-proksi manajemen laba berdasarkan model pengukuran yang digunakan. Mengakumulasi ukuran efek dan menghitung korelasi rata-rata (average correlation coefficient $(\Gamma)$ ), dengan rumus dari Ahmed dan Courtis (1999), Lion (2000):

$$
\overline{\mathbf{r}}=\Sigma\left(\mathbf{N}_{\mathbf{i}} \mathbf{r}_{\mathbf{i}}\right) / \Sigma \mathbf{N}_{\mathbf{i}}
$$

Dimana:

$\mathrm{N}_{\mathrm{i}}=$ Jumlah subyek dalam penelitian

$r^{-}=$Ukuran efek setiap penelitian 
Menghitung dan mengoreksi variansi kesalahan (error variance).

Tahap I:

$$
S^{2} e=\left(1-\bar{r}^{2}\right)^{2} K / \Sigma N_{i}
$$

Dimana:

$\mathrm{K}$ = Jumlah penelitian di dalam analisis

$\mathrm{S}^{2} \mathrm{e}=$ Estimasi sampling error variance

Tahap II:

$$
S^{2} \mathbf{p}=\mathbf{S}^{2} \mathbf{r}-\mathbf{S}^{2} \mathbf{e}
$$

Dimana:

$\mathrm{S}^{2} \mathrm{p}=$ Variance populasi sesungguhnya

$\mathrm{S}^{2} \mathrm{r}=$ Total variance yang diamati

Setelah menghitung estimasi korelasi dan variance populasi rata-rata, tahapan berikutnya menentukan apakah ada variabel-variabel moderasi (moderating variable) yaitu faktorfaktor lain (ketiga) yang bisa mempengaruhi hubungan-hubungan (korelasi-korelasi) yang diteliti. Sebuah variabel moderasi adalah variabel yang menyebabkan perbedaan dalam korelasi antara dua variabel lain (Ahmed dan Courtis, 1999). Penelitian ini menggunakan uji Chi-square berdasarkan Hunter dkk (1990) untuk menentukan apakah terdapat variabelvariabel moderasi atau tidak, dengan formula berikut:

$$
\chi_{K-1}^{2}=\frac{N}{\left(1-\dot{r}^{2}\right)} S_{r}^{2}
$$

Jika uji Chi-square menghasilkan nilai tidak signifikan, berarti hasil penelitian-penelitian yang dianalisis adalah homogen, hal ini memberi indikasi tidak ada variabel moderasi, sehingga dapat disimpulkan bahwa perbedaan antara korelasi yang ada (hubungan antara berbagai faktor yang mempengaruhi manajemen laba) adalah kesalahan statistik dan bukan kesalahan fungsi dari beberapa variabel moderasi (Ahmed dan Courtis, 1999), Jika uji Chi-square menghasilkan nilai yang signifikan, berarti terjadi heterogenitas sehingga diperlukan memasukkan variabel moderasi. Artinya, variasi hasil-hasil penelitian yang ada dimoderasi oleh variabel lain. Penelitian ini akan menggunakan pengukuran sebagai variabel moderasi, baik untuk akrual (proksi manajemen laba) maupun untuk varibel-varibel yang mempengaruhi manajemen laba.

\section{HASIL DAN PEMBAHASAN}

Hasil pencarian diperoleh beberapa jurnal terakreditasi yaitu Jurnal Akuntansi dan Keuangan Indonesia, Jurnal Riset Akuntansi Indonesia, Jurnal Akuntansi, Akuntabilitas, Jurnal Akuntansi dan Auditing Indonesia yang terbit sejak tahun 2000-2012.

Pencarian artikel juga dilakukan dengan mengunduh website jurnal LIPI, google.com, proquest, ebsco, sciencedirect, emerald. Selaian itu pencarian juga dilakukan terhadap artikel 
penelitian manajemen laba yang telah diseminarkan pada Simposium Nasional Akuntansi (SNA).

Hasil pencarian mendapatkan laporan hasil penelitian tentang berbagai variabel yang mempengaruhi manajemen laba di Indonesia selama periode penelitian dari tahun 2000 sampai dengan tahun 2012. Seleksi penelitian yang dimasukkan dalam sampel penelitian dilakukan dengan mengidentifikasi artikel penelitian yang relevan berdasarkan kriteria yang telah ditentukan. Inklusi variabel penelitian yang dijadikan obyek penelitian (masuk analisis) adalah variabel yang telah diteliti dan dilaporkan minimal oleh dua penelitian. Hasil identifikasi terhadap artikel hasil penelitian ditemukan 35 artikel yang memenuhi persyaratan/kriteria. Beberapa penelitian yang tidak masuk dalam kriteria disebabkan beberapa alasan seperti, tidak melaporkan nilai statistik $r$ maupun nilai statistik yang dapat dikonversi ke $r$ statistic ( $t$ statistic dan $p$. value). Beberapa penelitian melaporkan variabel yang sama dan diteliti oleh peneliti yang sama, sehingga hanya satu dari penelitian tersebut yang dimasukkan dalam analisis.

Semua artikel yang diidentifikasi dan masuk analisis menggunakan discretionary accrual sebagai proksi dari manajamen laba. Bentuk pengukuran dari discretionary accrual sendiri ada berbagai macam, antara lain, model Jones Model (1991), Modified Jones Model (1991), Modified Jones model in Dechow (1995), Modified Jones Model in Kasznik (1999), model Sankar (1994), Modified Jones in Kothari, Leone, Wasley (2005) dan forward looking abnormal accrual (Dechow, dkk, 2003). Untuk variabelvariabel independen terdiri dari karakteristik perusahaan yang diproksi melalui ukuran perusahaan, tingkat leverage, tingkat pertumbuhan, total arus kas bersih dari aktivitas operasi (CFO) dan profitabilitas. Selain karakteristik perusahaan, analisis juga dilakukan terhadap asimetri informasi.

Hasil analisis meta secara keseluruhan pengaruh variabel explanatory (karakteristik perusahaan, asimetri informasi terhadap manajemen laba nampak pada tabel 1 , berikut:

Tabel 1. Meta-Analysis for All Each Explanatory Variables

\begin{tabular}{|c|c|c|c|c|c|c|c|c|c|}
\hline $\begin{array}{l}\text { Explanatory } \\
\text { Variables }\end{array}$ & Sample & Study & $\mathbf{r}$ & $S_{r}^{2}$ & $S_{e}^{2}$ & $S_{p}^{2}$ & $\begin{array}{c}\text { Percentage } \\
\text { Explained }\end{array}$ & $\begin{array}{l}\text { 95\% Confidence } \\
\text { Interval }\end{array}$ & $X_{k-1}^{2}$ \\
\hline Corp Size & 5574 & 33 & $0.0746^{*}$ & 0.0785 & 0.0058 & 0.0727 & 0.0745 & $0.0678-0,2172$ & $442.8071^{* *}$ \\
\hline Leverage & 4560 & 26 & $0,0785^{*}$ & 0,0883 & 0,0056 & 0,0827 & 0,0638 & $0,0734-0,2406$ & $407.8136 * *$ \\
\hline Growth & 718 & 9 & $0,0676^{*}$ & 0,0724 & 0,0124 & 0,0600 & 0,1713 & $0,0501-0,1854$ & $52.5253^{* *}$ \\
\hline Profitability & 565 & 8 & 0,0538 & 0,2163 & 0,0140 & 0,2023 & 0,0651 & $-0,3427-0,4504$ & $122.9689 * *$ \\
\hline CFO & 73 & 5 & $-0,5283^{* *}$ & 0.1182 & 0.0020 & 0.1162 & 0.0173 & $-0.7562-0.3005$ & $289.8275^{* *}$ \\
\hline $\begin{array}{l}\text { Information } \\
\text { Asymmetry }\end{array}$ & 395 & 6 & $0.5489 * *$ & 0,1344 & 0.0074 & 0.1270 & 0.0552 & 0.30000 .7979 & $108.7871^{* *}$ \\
\hline
\end{tabular}

*Significant $<5 \%, * *$ Significant at $<1 \%$, Sumber: data diolah $(2018)$ 
Untuk variabel corporate size terdapat 33 studi yang dianalisis dimana ada 10 studi yang melaporkan effect size yang negatif dari pengaruh corporate size terhadap manajemen laba. Namun demikian, hasil analisis meta menemukan corporate size mempengaruhi manajemen laba secara positif signifikan, tetapi memilki korelasi yang lemah, ini terlihat dari mean correlation $\left(r^{-}\right)=0,0746$ dengan confidence interval 95\% antara 0,0678; 0,2172. Dari hasil perhitungan observasi variance $\left(\mathrm{Sr}^{2}\right)$ menunjukkan tingkat variasi yang tinggi terhadap 33 penelitian dan kekuatan explanatory yang rendah dari variance yang diamati. Hasil yang menunjukkan pengaruh positif signifikan, mendukung hipotesis bahwa corporate size berpengaruh terhadap manajemen laba.

Duabelas dari 26 studi yang meneliti pengaruh leverage terhadap manajemen laba melaporkan effect size yang negatif, dan hasilnya didapatkan nilai mean correlation $\left(\mathrm{r}^{-}\right.$) $=0,0785$ dengan confidence interval 95\% antara 0,0734; 0,2406, ini menunjukkan bahwa terdapat pengaruh positif signifikan tapi lemah. Observasi variance $\left(\mathrm{Sr}^{2}\right)$ juga menunjukkan tingkat variasi yang tinggi terhadap 26 penelitian dan kekuatan explanatory rendah dari variance yang diamati. Berdasarkan temuan ini, hipotesis bahwa leverage berpengaruh terhadap manajemen laba dapat didukung.

Analisis terhadap 9 studi yang meneliti pengaruh pertumbuhan perusahaan (growth) terhadap manajemen laba, menghasilkan mean correlation $\left(r^{-}\right)=0,0676$ dengan confidence interval 95\% antara 0,0501; 0,1854. Hasil tersebut menunjukkan ada pengaruh positif signifikan antara pertumbuhan (growth) terhadap manajemen laba. Dengan demikian, mendukung hipotesis bahwa growth berpengaruh terhadap manajemen laba. namun korelasinya sangat lemah dan observasi variance $\left(\mathrm{Sr}^{2}\right)$ tinggi terhadap 9 penelitian. Effect size pengaruh profitabilitas terhadap manajemen laba umumnya positif dari laporan studi yang dianalisis. Temuan analisis-meta menunjukkan profitabilitas tidak secara signifikan berpengaruh terhadap manajemen laba $\left(r^{-}=0,0538\right)$ dengan confidence interval $95 \%$ antara $-0,3427 ; 0,4504$. Dengan demikian hipotesis bahwa profitabilitas berpengaruh terhadap manajemen laba tidak dapat diterima.

Analisis terhadap pengaruh antara cash flow from operation (CFO) dengan manajemen laba melibatkan 5 studi. Temuan menunjukkan mean correlation $\left(r^{-}\right)=-0,5283$ dengan confidence interval 95\% antara -0,7562; 0,3005. Hasil ini menunjukkan bahwa Casf flow from operation $(\mathrm{CFO})$ berpengaruh negatif signifikan terhadap manajemen laba, dengan korelasi yang kuat. Observasi variance $\left(\mathrm{Sr}^{2}\right)$ menunjukkan tingkat variasi yang tinggi terhadap 5 penelitian dan kekuatan explanatory yang rendah dari variance yang diamati. Temuan analisis meta terhadap variabel cash flow from operation ini memberi dukungan terhadap hipotesis yang menyatakan casf flow from operation berpengaruh terhadap manajemen laba.

Analisis-meta asimetri informasi terhadap manajemen laba dilakukan terhadap 6 studi. Temuan menunjukkan mean correlation $\left(\mathrm{r}^{-}\right)=0,5489$, dengan confidence interval $95 \%$ antara 0,$3000 ; 1,7979$, ini berarti terdapat pengaruh yang positif signifikan dan memliki korelasi yang kuat pengaruh asimetri informasi terhadap manajemen laba. Temuan ini, memberi dukungan hipotesis yang menyatakan bahwa asimetri informasi berpengaruh terhadap manajemen laba. 
Bukti empiris yang didapatkan dari analisis-meta ini, sekalipun mendukung hipotesis yang ada namun pengaruhnya lemah, sehingga tidak cukup kuat (robust) untuk menyatakan corporate size berpengaruh positif terhadap manajemen laba. Temuan yang tidak robust terhadap tanda yang positif ini, memberi indikasi bahwa perusahaan-perusahaan yang berskala kecil di Indonesia kemungkinan melakukan manajemen laba (terdapat korelasi negatif). Indikasi ini terlihat dengan effect size yang dilaporkan oleh studi yang masuk analisis lebih dari 50\% dari total studi melaporkan effect size yang negatif.

Temuan empiris analisis-meta ini memiliki implikasi bahwa bukti adanya pengaruh positif ukuran perusahaan terhadap manajemen laba sebagai sinyal bahwa perusahaan besar melakukan manajemen laba. Namun, ditemukannya bukti yang lemah bahwa semakin besar perusahaan semakin besar manajemen labanya karena ada kemungkinan manajemen laba pada perusahaan besar sudah lebih terencana, bukan hanya menggunakan kebijakan akrual, sehingga lebih sulit terdeteksi. Dengan demikian perlu untuk mempertimbangkan cara pendeteksian manajemen laba yang terintegrasi baik deteksi secara kuantitatif maupun deteksi secara kualitatif.

Hasil analisis-meta moderator effect variabel dependen diperoleh bukti bahwa pengukuran variabel dependen yaitu discretionary accrual memoderasi pengaruh corporate size dengan manajemen laba. Hal ini berarti pengukuran terhadap manajemen laba mempengaruhi hasil yang didapatkan dari studi-studi sebelumnya. Bukti empiris ini memberi implikasi bahwa perlunya memperhatikan model ukuran manajemen laba yang digunakan dalam menguji pengaruh corporate size terhadap manajemen laba.

Hasil analisis-meta moderator effect variabel independen memberi bukti bahwa pengukuran terhadap corporate size, tidak mempengaruhi hasil dari studi-studi sebelumnya, atau dengan kata lain variasi hasil studi sebelumnya bukan disebabkan oleh pengukuran corporate size. Variabel corporate size yang diukur berdasarkan market capitalization, total asset maupun total sales, ditemukan positif signifikan secara kuat berpengaruh terhadap manajemen laba. Dengan demikian dapat disimpulkan bahwa berdasarkan ukuran corporate size yang digunakan dalam studi yang dianalisis, corporate size menunjukkan kekuatan explanatory yang tinggi terhadap manajemn laba.

Analisis-meta total sampel mengindikasikan ada pengaruh positif sekalipun lemah, antara corporate size dengan manajemen laba, artinya semakin besar ukuran perusahaan akan semakin tinggi tingkat manajemen labanya. Sejalan dengan political cost hypothesis bahwa semakin besar perusahaan, semakin besar kemungkinan perusahaan tersebut memilih metoda akuntansi yang menurunkan laba. Hal tersebut dikarenakan dengan laba yang tinggi regulator akan segera mengambil tindakan, misalnya, mengenakan peraturan antitrust, menaikkan pajak pendapatan perusahaan, dan lain-lain. Dengan kata lain perusahaan-perusahaan besar menghadapi lebih banyak tekanan untuk melaporkan laba yang besar, dan memiliki kemampuan lebih tinggi untuk melakukan manuver berbagai kebijakan akuntansi yang ada dalam mengelola laba yang dilaporkan.

Analisis efek moderator dilakukan untuk menentukan apakah hubungan variabel explanatory dengan variabel dependen dimoderasi oleh variabel lain. Hasil analisis-meta 
efek moderator variabel dependen dan explanatory tampak pada tabel 2 untuk variabel Corporate Size dan Leverage, dan pada tabel 3 untuk variabel pertumbuhan (Growth), Profitabilitas, dan CFO. Ringkasan hasil uji hipotesis analisis-meta total sampel, efek moderator variabel dependen dan variabel indepen tampak pada tabel 4, 5 dan 6 .

Tabel 2. Meta-Analisis Moderator Effect Dependent \& Explanatory Variables: Corporate Size \& Leverage

\begin{tabular}{|c|c|c|c|c|c|c|c|c|c|}
\hline & Sample & Study & $\mathbf{r}$ & $S_{r}^{2}$ & $S_{e}^{2}$ & $S_{p}^{2}$ & $\begin{array}{c}\% \\
\text { Expl }\end{array}$ & $\begin{array}{c}\text { Confidence } \\
\text { Interval }\end{array}$ & $X_{k-1}^{2}$ \\
\hline \multicolumn{10}{|l|}{ Corporate Size } \\
\hline \multicolumn{10}{|l|}{ Dependent var } \\
\hline Jones Model & 753 & 5 & 0,0166 & 0,0609 & 0,0066 & 0,0543 & 0,1088 & $\begin{array}{c}-0,0899 \\
0,1231\end{array}$ & $45,9363^{* *}$ \\
\hline Modified Jones & 932 & 6 & $0,1422^{*}$ & 0,0235 & 0,0061 & 0,0174 & 0,2621 & $\begin{array}{l}0,1082 \\
0,1764\end{array}$ & $22,8953^{* *}$ \\
\hline MJ in Dechow & 1703 & 10 & $0,2067^{*}$ & 0,1223 & 0,0053 & 0,1170 & 0,0440 & $\begin{array}{c}-0,0226 \\
0,4361\end{array}$ & $227,4771^{* *}$ \\
\hline MJ in Kasznik & 1012 & 6 & 0,0506 & 0,1051 & 0,0058 & 0,0992 & 0,0561 & $\begin{array}{c}-0,1438 \\
0,2452\end{array}$ & $106,9501^{* *}$ \\
\hline MJ in Kothari & 224 & 2 & $-0,1158$ & 7,0469 & 0,0086 & 0,0086 & 0,3251 & $\begin{array}{c}-0,0989 \\
0,1327\end{array}$ & 0,0162 \\
\hline Other model & 1174 & 6 & $-0,0195$ & 0,0825 & 0,0051 & 0,0774 & 0,0619 & $\begin{array}{c}-0,1713 \\
0,1323\end{array}$ & $96,9839 * *$ \\
\hline \multicolumn{10}{|l|}{ Independent } \\
\hline $\begin{array}{l}\text { Market } \\
\text { capitalization }\end{array}$ & 1543 & 9 & $0,0757^{*}$ & 0,0996 & 0,0057 & 0,0939 & 0,0578 & $\begin{array}{c}-0,1083 \\
0,2598\end{array}$ & $155,5842^{* *}$ \\
\hline Total asset & 2826 & 18 & $0,1419 *$ & 0,1289 & 0,0061 & 0,1228 & 0,0474 & $\begin{array}{c}-0,0989 \\
0,3827\end{array}$ & $379,6318^{* *}$ \\
\hline Total Sales & 163 & 2 & $0,2170^{*}$ & 8,9890 & 0,0111 & 0,0110 & 0,9457 & $\begin{array}{c}-0,2387 \\
0,1953\end{array}$ & $0,0161^{* *}$ \\
\hline \multicolumn{10}{|l|}{ Leverage } \\
\hline \multicolumn{10}{|l|}{ Dependent Var } \\
\hline Jones Model & 753 & 5 & 0,0480 & 0,1169 & 0,0066 & 0,1102 & 0,0565 & $\begin{array}{c}-0,1681 \\
0,2643\end{array}$ & $88,4408^{* *}$ \\
\hline Modified Jones & 872 & 5 & $-0,0300$ & 0,0101 & 0,0057 & 0,0043 & 0,5657 & $\begin{array}{l}-0,0387 \\
-0,0214\end{array}$ & 8,8381 \\
\hline MJ in Dechow & 913 & 6 & 0,0938* & 0,1487 & 0,0064 & 0,1422 & 0,0434 & $\begin{array}{c}-0,1849 \\
0,3727\end{array}$ & $138,1913^{* *}$ \\
\hline MJ in Kasznik & 788 & 4 & $0,1516^{*}$ & 0,1063 & 0,0048 & 0,1014 & 0,0456 & $\begin{array}{c}-0,0472 \\
0,3506\end{array}$ & $87,7787^{* *}$ \\
\hline MJ in Kothari & 224 & 2 & 0,0522 & 0,0173 & 0,0088 & 0,0084 & 0,5113 & $\begin{array}{l}0,0357 \\
0,0689\end{array}$ & 3,9112 \\
\hline Other Model & 1010 & 4 & $0,1298^{*}$ & 0,0633 & 0,0038 & 0,0594 & 0,0605 & $\begin{array}{l}0,0133 \\
0,2465\end{array}$ & $66,1579 * *$ \\
\hline \multicolumn{10}{|l|}{ Independent } \\
\hline Debt/Asset & 3503 & 19 & $0,1126^{*}$ & 0,0867 & 0,0052 & 0,0814 & 0,0609 & $\begin{array}{c}-0,0470 \\
0,2723\end{array}$ & $311,7625^{* *}$ \\
\hline Debt/Equity & 926 & 5 & $0,1064^{*}$ & 0,0249 & 0,0052 & 0,0196 & 0,2113 & $\begin{array}{l}0,0679 \\
0,1451\end{array}$ & $23,6598^{* *}$ \\
\hline
\end{tabular}

*Significant $<5 \%, * *$ Significant $<1 \%$, Sumber: data diolah $(2018)$ 
Hasil analisis-meta mengindikasikan ada pengaruh positif sekalipun lemah, antara tingkat leverage dengan manajemen laba artinya semakin tinggi leverage perusahaan semakin tinggi tingkat manajemen labanya. Sejalan dengan debt covenant hipothesis, bahwa terdapat hubungan positif antara tingkat leverage dengan manajemen laba. Manager pada perusahaan yang mempunyai tingkat leverage tinggi akan cenderung melakukan income increasing accruals untuk menghindari pelanggaran batasan hutang, atau sebaliknya, dimana perusahaan yang mengalami tekanan keuangan kemungkinan melakukan incoming decreasing accruals agar dapat melakukan renegoisasi kontrak utang.

Tabel 3. Meta-Analisis Moderator Effect Dependent \& Explanatory Variables: Growth, Profitability.

\begin{tabular}{|c|c|c|c|c|c|c|c|c|c|}
\hline & Sample & Study & $\mathbf{r}$ & $S_{r}^{2}$ & $S_{e}^{2}$ & $S_{p}^{2}$ & $\begin{array}{c}\% \\
\text { Explained }\end{array}$ & $\begin{array}{c}\text { Confidence } \\
\text { Interval }\end{array}$ & $X_{k-1}^{2}$ \\
\hline \multicolumn{10}{|l|}{ Growth } \\
\hline \multicolumn{10}{|l|}{ Dependent Var } \\
\hline Jones Model & 109 & 2 & $0,5685^{*}$ & 0,1056 & 0,1056 & 0,0084 & 0,0972 & $0,3780 \quad 0,7591$ & $25,1358^{* *}$ \\
\hline MJ in Dechow & 147 & 2 & $-0,0413$ & 0,0338 & 0,0135 & 0,0202 & 0,4009 & $-0,08100,0016$ & 4,9887 \\
\hline MJ in Kasznik & 288 & 2 & 0.0142 & 0,0005 & 0,0069 & 0,0064 & 0,1547 & $-0,02680,0017$ & 12,9269 \\
\hline \multicolumn{10}{|l|}{$\begin{array}{l}\text { Independent } \\
\text { var }\end{array}$} \\
\hline Everage sales & 456 & 6 & $-0,1350$ & 0,0912 & 0,0126 & 0,0786 & 0,1389 & $-0,28910,0190$ & $43,1878^{* *}$ \\
\hline Other & 262 & 3 & $-0,0044$ & 0,0216 & 0,0114 & 0,0102 & 0,5287 & $-0,02455,6739$ & 5,6739 \\
\hline \multicolumn{10}{|l|}{ Profitability } \\
\hline \multicolumn{10}{|l|}{ Dependent Var } \\
\hline Jones Model & 174 & 3 & $0,1769 *$ & 0,0147 & 0,0161 & 0,0014 & 1,0995 & $0,17980,1741$ & 2,7285 \\
\hline MJ in Dechow & 111 & 2 & $0,3434^{*}$ & 0,2100 & 0,0140 & 0,1960 & 0,0667 & $-0,0408 \quad 0,7278$ & 29,9744 \\
\hline \multicolumn{10}{|l|}{$\begin{array}{l}\text { Independent } \\
\text { Variable }\end{array}$} \\
\hline NP/Equity & 114 & 2 & $0,6333^{*}$ & 0,0088 & 0,0062 & 0,0025 & 0,7144 & $0,62850,6383$ & 2,7996 \\
\hline NP/Total Asset & 367 & 5 & $0,1415^{*}$ & 0,1862 & 0,0130 & 0,1732 & 0,0702 & $0,19790,4810$ & $71,1928^{* *}$ \\
\hline
\end{tabular}

*Significant at $<5 \%$, **Significant at $<1 \%$, var: variable, Sumber: Data diolah (2018)

Hasil analisis-meta total sampel mendapatkan bukti ada pengaruh positif sekalipun lemah antara tingkat pertumbuhan perusahaan (growth) dengan manajemen laba, artinya bahwa semakin tinggi pertumbuhan perusahaan, perusahaan akan semakin mengola labanya. Hasil penelitian ini konsisten dengan hasil penelitian yang dilakukan oleh Sun dan Rath (2009), dengan konteks yang berbeda. Penelitian Sun dan Rath (2009), mengambil sampel secara komprehensif terhadap tindakan manajemen laba yang dilakukan oleh perusahaan-perusahaan di Australia. Penelitian tersebut menemukan discretionary accrual yang tinggi cenderung terjadi pada perusahaan yang mengalami pertumbuhan yang tinggi. Hal ini dapat dijelaskan bahwa perusahaan yang mengalami 
pertumbuhan mungkin akan lebih mudah untuk terlibat dalam manajemen laba dibandingkan dengan perusahaan yang sudah matang (mature firms), karena sulit untuk mengamati kegiatan bisnis perusahaan berkembang pesat. Dengan demikian, manajer perusahaan dengan pertumbuhan yang tinggi cenderung memiliki insentif yang kuat untuk memenuhi target laba. Disamping itu, untuk menjaga agar pertumbuhan tetap konsisten, perusahaan yang sedang mengalami pertumbuhan akan cenderung melakukan pemerataan pendapatan.

Tabel 4. Ringkasan Hasil Uji hipotesis Analisis-Meta Total Sampel

\begin{tabular}{|c|c|c|c|c|c|}
\hline Sampel/Studi & $\begin{array}{l}\text { Variabel } \\
\text { Dependen }\end{array}$ & $\begin{array}{c}\text { Variabel } \\
\text { Independen }\end{array}$ & $\begin{array}{c}\text { Coeffisien } \\
\text { Correlation(r) }\end{array}$ & Hasil & Keterangan \\
\hline $5574 / 33$ & $\begin{array}{l}\text { Discretionary } \\
\text { accruals }\end{array}$ & Corporate size & $0,0746^{*}$ & $\begin{array}{l}\text { Positif signifikan } \\
\text { (lemah) }\end{array}$ & Didukung \\
\hline $4560 / 26$ & $\begin{array}{l}\text { Discretionary } \\
\text { accruals }\end{array}$ & Leverage & $0,0785^{*}$ & $\begin{array}{l}\text { Positif signifikan } \\
\text { (lemah) }\end{array}$ & Didukung \\
\hline $18 / 9$ & $\begin{array}{l}\text { Discretionary } \\
\text { accruals }\end{array}$ & Growth & $0,0676^{*}$ & $\begin{array}{l}\text { Positif signifikan } \\
\text { (lemah) }\end{array}$ & Didukung \\
\hline $565 / 8$ & $\begin{array}{l}\text { Discretionary } \\
\text { accruals }\end{array}$ & Profitabilitas & 0,0538 & Tidak signifikan & $\begin{array}{c}\text { Tidak } \\
\text { didukung }\end{array}$ \\
\hline $1273 / 5$ & $\begin{array}{l}\text { Discretionary } \\
\text { accruals }\end{array}$ & CFO & $-0,5283^{* *}$ & $\begin{array}{c}\text { Negatif signifikan } \\
\text { (Kuat) }\end{array}$ & Didukung \\
\hline $395 / 6$ & $\begin{array}{l}\text { Discretionary } \\
\text { accruals }\end{array}$ & $\begin{array}{l}\text { Asimetri } \\
\text { informasi }\end{array}$ & $0,5489 * *$ & $\begin{array}{l}\text { Positif signifikan } \\
\text { (Kuat) }\end{array}$ & Didukung \\
\hline
\end{tabular}

*Signifikan $<5 \%,{ }^{* *}$ Signifikan $<1 \%$. Sumber: Data diolah $(2018)$

Analisis-meta total sampel memperoleh bukti empiris bahwa tidak ada pengaruh signifikan antara profitabilitas dengan manajemen laba. Dengan kata lain variabel profitabilitas tidak mampu memprediksi adanya manajemen laba yang dilakukan perusahaan. Bukti yang mendukung bahwa profitabilitas mempengaruhi manajemen laba didapatkan pada analisis-meta perkelompok yang mendapatkan bukti positif signifikan. Bukti positif signifikan didapatkan pada semua kelompok, baik kelompok pengukuran variabel dependen (discretionary accrual) yaitu Jones model (1991), maupun modified Jones in Dechow dkk (1995), maupun pada kelompok pengukuran variabel independen (profitabilitas) yaitu net profit/equity dan net profit/total asset. Kondisi ini mendukung teori bahwa profitabilitas mempengaruhi tingkat manajemen laba dan laba akuntansi yang lebih rendah memberikan motivasi bagi perusahaan untuk mengatur laba karena perusahaan-perusahaan ini mungkin menghadapi kendala keuangan (teori agensi). Namun demikian, analisis-meta dalam penelitian ini belum bisa memberi bukti yang kuat (robust) karena bukti tersebut berdasarkan pada anallisis perkelompok yang memiliki sampel kecil. 
Tabel 5. Ringkasan Hasil Uji Moderator Effect: Variabel Dependen

\begin{tabular}{|c|c|c|c|c|c|c|}
\hline $\begin{array}{c}\text { Sampel } \\
\text { Studi }\end{array}$ & $\begin{array}{c}\text { Independen } \\
\text { variable }\end{array}$ & Moderasi & \multicolumn{2}{|c|}{$\begin{array}{c}\text { Coeffisien } \\
\text { Correlation }\end{array}$} & Hasil & Keterangan \\
\hline \multirow{6}{*}{$5574 / 33$} & \multirow{6}{*}{$\begin{array}{l}\text { Corporate } \\
\text { size }\end{array}$} & \multirow{6}{*}{$\begin{array}{c}\text { Model } \\
\text { Ukuran ML }\end{array}$} & JM(1991) & 0,0166 & \multirow{6}{*}{$\begin{array}{c}\text { Variatif } \\
\text { Tidak } \\
\text { konsisten }\end{array}$} & \multirow{6}{*}{ Didukung } \\
\hline & & & MJM & $0,1422^{*}$ & & \\
\hline & & & MJ Dechow & $0,2067^{*}$ & & \\
\hline & & & MJ Kasznik & 0,0506 & & \\
\hline & & & MJ Kothari & $-0,1158$ & & \\
\hline & & & Model Lain & $-0,0195$ & & \\
\hline \multirow{6}{*}{$4560 / 26$} & \multirow{6}{*}{ Leverage } & \multirow{6}{*}{$\begin{array}{c}\text { Model } \\
\text { Ukuran ML }\end{array}$} & JM & 0,0480 & & \multirow{6}{*}{ Didukung } \\
\hline & & & MJM & $-0,0300$ & & \\
\hline & & & MJ Dechow & 0,0938* & Variatif & \\
\hline & & & MJ Kasznik & $0,1516^{*}$ & konsisten & \\
\hline & & & MJ Kothari & 0,0522 & & \\
\hline & & & Model Lain & $0,1298^{*}$ & & \\
\hline \multirow{3}{*}{$544 / 6$} & \multirow{3}{*}{ Growth } & \multirow{3}{*}{$\begin{array}{c}\text { Model } \\
\text { Ukuran ML }\end{array}$} & JM & $0,5685^{*}$ & Variatif & \multirow{3}{*}{ Didukung } \\
\hline & & & MJ Dechow & $-0,0413$ & Tidak & \\
\hline & & & MJKasznik & 0,0142 & konsisten & \\
\hline \multirow{2}{*}{$285 / 5$} & \multirow{2}{*}{ Profitabilitas } & & JM & $0,1769^{*}$ & Variatif & \multirow{2}{*}{ Didukung } \\
\hline & & Ukuran ML & MJ Dechow & $0,3434^{*}$ & $\begin{array}{c}\text { Tidak } \\
\text { konsisten }\end{array}$ & \\
\hline
\end{tabular}

*Signifikan $<5 \%, * *$ Signifikan $<1 \%$. Sumber: Data diolah $(2018)$

Tabel 6. Moderator Effect: Variabel Independen

\begin{tabular}{|c|c|c|c|c|c|c|}
\hline Sampel/Studi & $\begin{array}{c}\text { Independen } \\
\text { variable }\end{array}$ & Moderasi & $\begin{array}{l}\text { Cor } \\
\text { Cor }\end{array}$ & $\begin{array}{l}\text { sien } \\
\text { ation }\end{array}$ & Hasil & Keterangan \\
\hline $4532 / 29$ & Corporate size & $\begin{array}{c}\text { Ukuran } \\
\text { Corporate size }\end{array}$ & $\begin{array}{l}\text { MC } \\
\text { TA } \\
\text { TS }\end{array}$ & $\begin{array}{l}0,0757^{*} \\
0,1419^{*} \\
0,2170^{*}\end{array}$ & $\begin{array}{l}\text { Konsisten } \\
\text { Positif } \\
\text { signifikan }\end{array}$ & $\begin{array}{c}\text { Tidak } \\
\text { Didukung }\end{array}$ \\
\hline $4429 / 24$ & Leverage & $\begin{array}{l}\text { Ukuran } \\
\text { Leverage }\end{array}$ & $\begin{array}{l}\mathrm{D} / \mathrm{A} \\
D / E\end{array}$ & $\begin{array}{l}0,1126^{*} \\
0,1064^{*}\end{array}$ & $\begin{array}{c}\text { Konsisten } \\
\text { Positif } \\
\text { signifikan }\end{array}$ & $\begin{array}{c}\text { Tidak } \\
\text { Didukung }\end{array}$ \\
\hline $718 / 9$ & Growth & $\begin{array}{l}\text { Ukuran } \\
\text { Growth }\end{array}$ & $\begin{array}{c}\text { ES } \\
\text { Others }\end{array}$ & $\begin{array}{c}-1350 \\
-0,0044\end{array}$ & $\begin{array}{c}\text { Variatif Tidak } \\
\text { konsisten }\end{array}$ & Didukung \\
\hline $481 / 7$ & Profitabilitas & $\begin{array}{c}\text { Ukuran } \\
\text { Profitabilitas }\end{array}$ & $\begin{array}{l}\mathrm{NP} / \mathrm{Eq} \\
\mathrm{NP} / \mathrm{TA}\end{array}$ & $\begin{array}{l}0,6333^{*} \\
0,1415^{*}\end{array}$ & $\begin{array}{c}\text { Variatif Tidak } \\
\text { konsisten }\end{array}$ & Didukung \\
\hline
\end{tabular}

*Signifikan < 5\%, **Signifikan < 1\%, Sumber: Data di olah (2018)

Hasil analisis-meta moderator effect variabel dependen diperoleh bukti bahwa bahwa pengukuran variabel dependen yaitu discretionary accrual memoderasi pengaruh profibilitas 
terhadap manajemen laba. Hal ini berarti bahwa pengukuran terhadap manajemen laba mempengaruhi hasil yang didapatkan dari studi-studi sebelumnya. Bukti empiris ini memiliki implikasi bahwa perlunya mempertimbangkan model ukuran manajemen laba yang lebih akurat dan spesifik dalam menguji pengaruh profitabiltas terhadap manajemen laba.

Konsisten dengan temuan $\mathrm{Gu}$, Lee dan Rosett (2005) yang melakukan penelitian dalam konteks yang berbeda, melaporkan bahwa variabilitas dari akrual secara positif terkait dengan leverage.

Temuan analisis-meta ini menunjukkan bukti yang belum cukup kuat (robust) untuk menyatakan bahwa variabel leverage berpengaruh positif terhadap manajemen laba, terlihat dari nilai korelasi yang lemah. Hal ini mengindikasikan bahwa perusahaan-perusahaan di Indonesia dengan leverage yang rendah ada kemungkinan melakukan praktik manajemen laba. Indikasi ini terlihat dengan effect size yang dilaporkan oleh studi yang masuk analisis hampir 50\% dari total studi melaporkan effect size yang negatif.

Temuan penelitian ini memiliki implikasi bahwa dampak dari leverage terhadap manajemen laba merupakan kontroversi empiris, sehingga merupakan sinyal untuk menekankan peran regulator dalam hal leverage perusahaan. Adanya hubungan negatif antara pendanaan utang dan penggunaan kekuasaan diskresi dalam keputusan akuntansi manajer, karena semakin tinggi leverage semakin tinggi kontrol yang diterapkan oleh pemberi pinjaman. Hal ini juga menunjukkan bahwa manajer perusahaan yang memiliki leverage tinggi memiliki motif yang lebih sedikit untuk mengelola laba karena ada kecenderungan para kreditur lebih tertarik pada pelayanan utang daripada informasi akuntansi, yang berarti bahwa laporan keuangan memiliki konten informasi kurang relevan dalam kasus ini. Bukti bahwa leverage berhubungan positif dengan diskresionari akrual terkait dengan kemungkinan melanggar perjanjian utang. Kedua argumen yang didukung oleh bukti empiris dan teori tersebut, belum dapat memberi jawaban yang subtantif, meskipun ditemukan bukti dalam penelitian analisis-meta ini bahwa ada pengaruh positif namun lemah. Oleh karena itu, jawaban tentang hubungan antara leverage dengan manajemen laba masih kontroversi.

Hasil analisis-meta moderator effect variabel dependen diperoleh bukti bahwa pengukuran variabel dependen yaitu discretionary accrual memoderasi pengaruh leverage dengan manajemen laba. Hal ini berarti bahwa pengukuran terhadap manajemen laba mempengaruhi hasil yang didapatkan dari studi-studi sebelumnya. Bukti empiris ini memberi implikasi bahwa perlunya memperhatikan model ukuran manajemen laba yang digunakan dalam menguji pengaruh leverage terhadap manajmene laba.

Hasil analisis-meta moderator effect variabel independen memberi bukti bahwa hipotesis tidak didukung. Hal ini berarti bahwa pengukuran terhadap leverage tidak mempengaruhi hasil dari studi-studi sebelumnya yang dianalisis, atau dengan kata lain variasi hasil dari studi sebelumnya bukan disebabkan oleh pengukuran leverage. Variabel leverage yang diukur berdasarkan debt/total asset maupun debt/total equity ditemukan positif signifikan secara kuat berpengaruh terhadap manajemen laba. Dengan demikian dapat disimpulkan bahwa dilihat berdasarkan ukuran leverage yang digunakan dalam studi yang dianalisis, leverage menunjukkan kekuatan explanatory yang tinggi terhadap manajemen laba. 
Bukti empiris yang didapatkan dari analisis-meta ini, sekalipun mendukung hipotesis yang ada namun pengaruhnya lemah, sehingga tidak cukup kuat (robust) untuk menyatakan tingkat pertumbuhan berpengaruh positif terhadap manajemen laba. Temuan yang tidak robust terhadap tanda yang positif ini, memberi indikasi bahwa perusahaan-perusahaan di Indonesia yang tidak dalam tingkat pertumbuhan tinggi kemungkinan melakukan manajemen laba (terdapat korelasi negatif). Indikasi ini terlihat dari temuan beberapa penelitian yang dianalisis melaporkan effect size negatif. Indikasi ini didukung oleh beberapa penelitian yang menemukan pengaruh negatif antara tingkat pertumbuhan dengan manajemen laba. Hal ini didukung juga oleh McNichols (2000), yang mengatakan bahwa perusahaan dengan tingkat pertumbuhan yang tinggi akan mempunyai akrual diskresioner yang tinggi yang lebih berkorelasi dengan kinerja perusahaan, bukan dengan insentif untuk melakukan manajemen laba. Temuan penelitian ini memiliki implikasi bahwa pengaruh tingkat pertumbuhan perusahaan (growth) terhadap manajemen laba merupakan kontroversi empiris, sehingga perlu pengembangan model pengukuran yang lebih akurat dan spesifik yang dapat mengidentifikasi perbedaan pola manajemen laba pada perusahaan-perusahaan di Indonesia.

Analisis-meta total sampel cash flow operation memperoleh bukti empiris bahwa hipotesis di dukung dengan korelasi negatif. Hal ini berarti ada pengaruh negatif yang cukup kuat (robust) antara casf flow from operation (CFO) dengan manajemen laba, dengan kata lain semakin besar $C F O$ akan semakin kecil kemungkinan perusahaan melakukan manajemen laba. Temuan analisis-meta ini konsisten dengan penelitian pada konteks yang berbeda yang dilakukan oleh Dechow dkk. (1995), Chen dkk (2005) dan Aussenegg dkk (2009). Penelitian yang dilakukan Chen dkk. menunjukkan bahwa arus kas operasi berpengaruh negatif dan signifikan terhadap manajemen laba. Aussenegg dkk. juga menemukan bukti bahwa arus kas operasi mampu membatasi manajemen laba pada perusahaan sampel di Eropa periode 1995-2005.

Temuan ini memiliki implikasi bahwa perusahaan dengan arus kas operasi (CFO) yang tinggi akan cenderung untuk tidak melakukan peningkatan laba (increase) melalui peningkatan discretionary accruals. Dengan demikian, mempertegas keyakinan bahwa arus kas dari aktivitas operasi mencerminkan kemampuan riil perusahaan dalam menghasilkan dana (arus dana). Artinya, jika arus kas dari aktivitas operasi perusahaan tinggi, motivasi untuk melakukan manajemen laba akan menurun karena perusahaan secara riil mampu menghasilkan dana yang cukup sehingga tidak perlu melakukan manajemen laba. Hal yang sebaliknya terjadi pada saat arus kas dari aktivitas operasi rendah, dimana manajemen akan termotivasi untuk menunjukkan perbaikan kinerja dengan melakukan manajemen laba.

Analisis-meta total sampel asimetri informasi memperoleh bukti empiris hipotesis didukung dengan korelasi positif. Hal ini berarti ada pengaruh positif yang kuat (robust) antara asimetri informasi dengan manajemen laba, dengan kata lain semakin tinggi asimetri informasi akan semakin besar kemungkinan perusahaan melakukan manajemen laba melalui discretionary accruals. Temuan ini konsisten dengan penelitian Richardson (2000) yang meneliti hubungan asimetri informasi dengan manajemen laba pada semua 
perusahaan yang terdaftar di NYSE. Hasil penelitiannya menunjukkan adanya hubungan positif signifikan antara ukuran ketidak seimbangan informasi (bid-ask spread) dengan manajemen laba. Temuan analisis meta ini juga sejalan dengan penelitian konteks berbeda oleh Hsin Cheng (2006) yang mengkaji hubungan asimetri informasi terhadap manajemen laba dengan lingkungan manajerial yang berbeda antara Barat dan Timur dengan melakukan komparasi dengan penelitian Richardson (2000). Hasil penelitiannya menyimpulkan ada pengaruh antara asimetri informasi terhadap manajemen laba. Dan hubungan pengaruh tersebut mungkin akan berbeda di berbagai negara diakibatkan karakteristik yang berbeda dari hak pemegang saham.

\section{SIMPULAN}

Hasil analisis-meta penelitian ini memperkuat temuan penelitian-penelitian sebelumnya bahwa manajemen laba dilakukan untuk tujuan yang berbeda. Beberapa atribut perusahaan ditemukan sebagai prediktor manajemen laba. Motivasi manajemen untuk melakukan manajemen laba, juga masih bervariasi, yaitu oportunis atau kontrak efisien. Temuan empiris analisis-meta penelitian ini menunjukkan bahwa di Indonesia perusahaan besar lebih banyak melakukan manajemen laba dibanding perusahaan kecil. Hal ini bukan berarti bahwa perusahaan kecil tidak melakukan manajemen laba, sehingga temuan ini perlu diinterpretasikan secara hati-hati karena efek positif yang didapat adalah lemah, oleh karena itu perlu mempertimbangkan bukti empiris yang ada bahwa baik perusahaan berukuran besar maupun perusahaan berukuran kecil mengelola laba untuk menghindari political cost maupun tujuan oportunis manajemen. Dampak dari pembiayaan utang dan tingkat pertumbuhan perusahaan terhadap manajemen laba masih merupakan kontroversi empiris yang memiliki efek positif dan negatif. Meskipun temuan analisismeta penelitian ini telah menunjukkan hubungan positif, bahwa leverage perusahaan yang tinggi meningkatkan manajemen laba, namun memberikan dukungan yang lemah terhadap debt covenant hipothesis.

Secara robust casf flow from operation sebagai karakteristik perusahaan dan asimetri informasi merupakan prediktor manajemen laba yang terbaik. Temuan ini memiliki argumen bahwa casf flow from operation yang tinggi perusahaan secara riil mampu menghasilkan dana yang cukup sehingga tidak perlu melakukan manajemen laba. Asimetri informasi yang tinggi akan mendorong manajer untuk melakukan manajemen laba. Hal ini dapat dijelaskan bahwa dengan asimetri informasi yang tinggi mengakibatkan principal tidak memiliki akses yang cukup untuk mendapatkan informasi yang relevan untuk mengawasi manajer (agen) yang memberi peluang bagi manajer untuk berindak oportunis. Pengukuran bukan hanya memiliki konsekuensi untuk model pengukuran manajemen laba akan tetapi juga untuk beberapa pengukuran variabel independen yaitu, pengukuran tingkat pertumbuhan (growth) dan pengukuran profitabilitas. Efek positif tingkat pertumbuhan terhadap manajemen laba didapatkan hanya pada model Jones (1991), yang memilki implikasi bahwa perusahaan yang sedang mengalami tingkat pertumbuhan yang tinggi lebih cenderung untuk mengatur labanya. Penelitian-penelitian yang masuk analisis dalam studi ini umumnya masih berdasar pada teori agensi dan teori akuntansi positif dalam 
menjelaskan motivasi manajemen melakukan manajemen. Analisis meta yang dilakukan memberi indikasi bahwa praktik manajemen laba terjadi bukan hanya karena adanya masalah keagenan (agency problem), akan tetapi banyak aspek lain yang memerlukan bukti-bukti empiris. Penelitian berikutnya perlu juga mempertimbangkan ide teori prospek yang dikembangkan Shen dan Chih (2005).

\section{PUSTAKA ACUAN}

Ali, S. Z., S. A. Butt., and A. Hasan. (2009). Corporate Governance and Earnings Management an Empirical Evidence Form Pakistani Listed Corporate. European Journal of Scientific Research. 26 (4). 624-638.

Ahmed, K., and J.K. Courtis. (1999). Associations between Corporate Characteristics and Disclosure Levels in Annual Reports: A Meta-analysis. British Accounting Review. 31 (1). 35-61.

Aussenegg, W., P. Inwinkl, and G. Schneider. (2009). Earnings Management and Accounting Standards in Europe. Proceedings of the 2009 MFA Annual Meeting.

Cheng C-H. 2006. Information Asymmetry and Earnings Management in Taiwanese Tech Industry. Corning journal 8. 99-112

Chtourou, S. M., J. Bedard, and L. Courteau. (2001). Corporate Governance and Earnings Management. Social Science Research Network (SSRN) http://paper.ssrn.com/ abstract $=275053$.

Dalton, D.R, Catherine M. D., S. Trevi. C, and R. Roengpitya. (2003) Meta-analysis of Financial Peformance and Equity: Fusion or confusion?. Academy of Management Journal. 46. 13-26

Dechow, P., and R. G. Sloan, and A. P. Sweeney. (1995). Detecting Earnings Management. The Accounting Review. April. 70 (2). 193-225.

Dechow, P. M., D. J. Skinner. (2000). Earnings Management: Reconciling the Views of Accounting Academics, Practitioners, and Regulators. American Accounting Association Accounting Horizons. 14 (2). 235-250.

Dechow,.P., S. A. Richardson and A,I,Tuna. (2003). Why are Earnings Kinky? An Examination of the Earnings Management Explanation. Review of Accounting Studies. 8 (2-3). 355-384.

García-Meca, E., and J. P. Sánchez-Ballesta. (2009). Corporate Governance and Earnings Management: A Meta-Analysis. Corporate Governance: An International Review. 17(5). 594-610.

$\mathrm{Gu}, \mathrm{Z}$, and C-W. J. Lee. (2002). How Widespread is Earnings Management? The Intra-year Timing Evidence. Working Paper. Carnegie-Mellon University

Gu. Z, C. W. J. Lee and J. G. Rosett. (2005). What Determines the Variability of Accounting Accruals?. Review of Quantitative Finance \& Accounting. 24(3). 313-334.

Healy, P.M. (1985). The Effect of Bonus Scheme on Accounting Decision. Journal of Accounting and Economics. 7 (1). 85-107. 
Hunter, J. E. and F. L Schmidt. (2004). Methods of Meta-analysis: Correcting Error and Bias in Research Findings. (2end ed.). Thousand Oaks, CA: Sage.

Kothari. S. P., A. J. Leone, and C. E. Wasley. (2005). Performance Matched Discretionary Accrual Measures. Journal of Accounting and Economics. 39. 163-197.

Lipsey, M.W. and D.B. Wilson. (2001). Practical Meta-analysis. Applied Social Research Methods, 49. Sage Publications, Inc. California.

Lobo, G. J. and J. Zhou. (2001). Disclosure Quality and Earnings Management. Social Science Research Network Electronic Paper Collection

Lyons. L. C. (2000). Meta- Analysis: Methods of Accumulating Results Across Research Domains. Email Solomon @mnsinc.com.

McNichols. M. (2000). Research Design Issues in Earningss Management Studies. Journal of Accounting and Public Policy. 19. 313-345.

Mulford, C. W., and E. E. Comiskey. (2002). The Financial Numbers Game Detecting Creative Accounting Theory. New York: John Wiley and Sons, Inc.

Richardson. V. J. (2000). Information Asymmetry and Earnings Management: Some Evidence. Review of Quantitative Finance and Accoaunting. 15 (4). 325-347.

Shen C-H, and H-L Chih. (2005). Investor protection, prospect theory, and earnings management: An international comparison of the banking industry. Journal of Banking \& Finance. 29. 2675- 2697

She. J. L. and M. Machfoedz. (1998). Faktor-Faktor yang Mempengaruhi Praktik Perataan Laba pada Perusahaan yang Terdaftar di Bursa Efek Jakarta. Jurnal Riset Akuntansi Indonesia. 1 (2). 174-191.

Sun L and S. Rath. (2009). An Empirical Analysis of Earnings Management in Australia. International Journal of Human and Social Sciences. 4 (14). 1069-1085.

Yangseon. K., L. Caixing, and S. R. Ghon. (2003). The Effect of Firm Size on Earnings Management. Available on-line rheesg@hawai.edu.

Zuhroh, D. (1996). Faktor-faktor yang Berpengaruh pada Tindakan Perataan laba pada Perusahaan Go Public di Indonesia. Universitas Gajah Mada. Yogyakarta. Tesis S2. Program Pasca Sarjana. 